\title{
Front Matter: Volume 9333
}

, "Front Matter: Volume 9333," Proc. SPIE 9333, Biomedical Applications of Light Scattering IX, (20 April 2015); doi: 10.1117/12.2192728

SPIE. Event: SPIE BiOS, 2015, San Francisco, California, United States 


\title{
PROGRESS IN BIOMEDICAL OPTICS AND IMAGING
}

\section{Biomedical Applications of Light Scattering IX}

\author{
Adam Wax \\ Vadim Backman \\ Editors
}

7-8 February 2015

San Francisco, California, United States

Sponsored and Published by

SPIE 
The papers included in this volume were part of the technical conference cited on the cover and title page. Papers were selected and subject to review by the editors and conference program committee. Some conference presentations may not be available for publication. The papers published in these proceedings reflect the work and thoughts of the authors and are published herein as submitted. The publisher is not responsible for the validity of the information or for any outcomes resulting from reliance thereon.

Please use the following format to cite material from this book:

Author(s), "Title of Paper," in Biomedical Applications of Light Scattering IX, edited by Adam Wax, Vadim Backman, Proceedings of SPIE Vol. 9333 (SPIE, Bellingham, WA, 2015) Article CID Number.

ISSN: $1605-7422$

ISBN: 9781628414233

Published by

SPIE

P.O. Box 10, Bellingham, Washington 98227-0010 USA

Telephone +1 3606763290 (Pacific Time) · Fax +1 3606471445

SPIE.org

Copyright (C) 2015, Society of Photo-Optical Instrumentation Engineers.

Copying of material in this book for internal or personal use, or for the internal or personal use of specific clients, beyond the fair use provisions granted by the U.S. Copyright Law is authorized by SPIE subject to payment of copying fees. The Transactional Reporting Service base fee for this volume is $\$ 18.00$ per article (or portion thereof), which should be paid directly to the Copyright Clearance Center (CCC), 222 Rosewood Drive, Danvers, MA 01923. Payment may also be made electronically through CCC Online at copyright.com. Other copying for republication, resale, advertising or promotion, or any form of systematic or multiple reproduction of any material in this book is prohibited except with permission in writing from the publisher. The CCC fee code is $1605-7422 / 15 / \$ 18.00$.

Printed in the United States of America.

Publication of record for individual papers is online in the SPIE Digital Library.

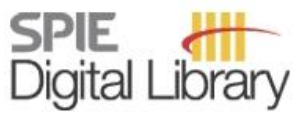

SPIEDigitalLibrary.org

Paper Numbering: Proceedings of SPIE follow an e-First publication model, with papers published first online and then in print. Papers are published as they are submitted and meet publication criteria. A unique citation identifier (CID) number is assigned to each article at the time of the first publication. Utilization of CIDs allows articles to be fully citable as soon as they are published online, and connects the same identifier to all online, print, and electronic versions of the publication. SPIE uses a six-digit CID article numbering system in which:

- The first four digits correspond to the SPIE volume number.

- The last two digits indicate publication order within the volume using a Base 36 numbering

system employing both numerals and letters. These two-number sets start with 00, 01, 02, 03, 04, $05,06,07,08,09,0 A, 0 B \ldots$. 0Z, followed by 10-1Z, 20-2Z, etc.

The CID Number appears on each page of the manuscript. The complete citation is used on the first page, and an abbreviated version on subsequent pages. 


\title{
Contents
}

\author{
$\checkmark$ Authors \\ vii Conference Committee
}

DYNAMIC LIGHT SCATTERING AND SPECKLE I

933302 Robust estimation of vessel misfocus and real-time misfocus correction in laser speckle contrast imaging [9333-2]

DYNAMIC LIGHT SCATTERING AND SPECKLE II

933304 Detection of early seizures by diffuse optical tomography [9333-4]

THEORY II

$9333 \mathrm{OE} \quad$ Investigation of the best model to characterize diffuse correlation spectroscopy measurements acquired directly on the brain [9333-14]

9333 OF Modeling scattering in turbid media using the Gegenbauer phase function [9333-15]

NOVEL TECHNIQUES

$9333 \mathrm{ON}$ Video-rate dual polarization multispectral endoscopic imaging [9333-24]

933300 Monte Carlo based investigation of Berry phase for depth resolved characterization of biomedical scattering samples [9333-25]

LOW COHERENCE LIGHT SCATTERING

9333 OV Efficient signal processing in spectroscopic optical coherence tomography [9333-32]

POSTER SESSION

9333 OW Analysis of water spread dynamics in human skin with near-infrared imaging [9333-33]

$9333 \mathrm{OZ}$ Computational hair quality categorization in lower magnifications [9333-36]

933310 Accuracy of experimental data and Monte Carlo simulation lookup table-based inverse models for assessment of turbid media optical properties with diffuse reflectance spectroscopy [9333-37] 
933312 Scatterers shape effect on speckle patterns [9333-39]

933313 Numerical modeling of photon migration in the cerebral cortex of the living rat using the radiative transport equation [9333-40]

933314 Advanced Monte Carlo simulator of the polarization-sensitive optical coherence tomography systems [9333-41]

933316 Electric field Monte Carlo study of coherent complex light in turbid media [9333-43] 


\title{
Authors
}

Numbers in the index correspond to the last two digits of the six-digit citation identifier (CID) article numbering system used in Proceedings of SPIE. The first four digits reflect the volume number. Base 36 numbering is employed for the last two digits and indicates the order of articles within the volume. Numbers start with 00, 01, 02, 03, 04, 05, 06, 07, 08, 09, 0A, 0B...0Z, followed by 10-1Z, 20-2Z, etc.

\author{
Arimoto, Hidenobu, OW \\ Arya, Shobhit, ON \\ Baba, J. S., 00 \\ Bregar, Maksimilijan, 10 \\ Bürmen, Miran, 10 \\ Calabro, Katherine W., OF \\ Cao, Zili, 16 \\ Carney, Paul R., 04 \\ Cassarly, William, OF \\ Clancy, Neil T., ON \\ Denisenkov, Valentin S., 12 \\ Diop, M., OE \\ Egawa, Mariko, oW \\ Elson, Daniel S., ON \\ Fujii, Hiroyuki, 13 \\ Hajihashemi, M. Reza, 04 \\ Hanna, George B., ON \\ Heshmat, Barmak, $\mathrm{OZ}$ \\ Hoshi, Yoko, 13 \\ Ikoma, Hayato, $\mathrm{OZ}$ \\ Jiang, Huabei, 04 \\ John, D., 00 \\ Kiyko, Vadim V., 12 \\ Koju, V., 00 \\ Kraszewski, Maciej, OV, 14 \\ Lee, Ik Hyun, 0 Z \\ Levi, Ofer, 02 \\ Likar, Boštjan, 10 \\ Lin, Xiaolei, 16 \\ Nadamoto, Ken, 13 \\ Naglič, Peter, 10 \\ Okada, Eiji, 13 \\ Okawa, Shinpei, 13 \\ Pernuš, Franjo, 10 \\ Pigula, Anne, ON \\ Pluciński, Jerzy, 14 \\ Raskar, Ramesh, $\mathrm{OZ}$ \\ Rastogi, Krishna, $\mathrm{OZ}$ \\ Ringuette, Dene, 02 \\ Sigal, lliya, 02 \\ St. Lawrence, K., OE \\ Strakowski, Marcin R., OV, 14 \\ Trojanowski, Michał, OV, 14 \\ Vdovin, Gleb V., 12 \\ Verdecchia, K., OE \\ Watanabe, Masao, 13 \\ $X \cup, M ., 16$ \\ Yamada, Yukio, 13 \\ Zeng, Bixin, 16
}

Zhang, Tao, 04

Zhou, Junli, 04

Zhu, Xiuwei, 16 
Proc. of SPIE Vol. $9333-6$

Downloaded From: https://www.spiedigitallibrary.org/conference-proceedings-of-spie on 26 Apr 2023 Terms of Use: https://www.spiedigitallibrary.org/terms-of-use 


\title{
Conference Committee
}

\author{
Symposium Chairs
}

James G. Fujimoto, Massachusetts Institute of Technology

(United States)

R. Rox Anderson, Wellman Center for Photomedicine,

Massachusetts General Hospital (United States) and Harvard School of Medicine (United States)

Program Track Chairs

Ammasi Periasamy, University of Virginia (United States)

Daniel L. Farkas, University of Southern California (United States)

Conference Chairs

Adam Wax, Duke University (United States)

Vadim Backman, Northwestern University (United States)

Conference Program Committee

Irving J. Bigio, Boston University (United States)

Stephen A. Boppart, University of Illinois at Urbana-Champaign (United States)

Dirk J. Faber, Academisch Medisch Centrum (Netherlands)

Steven L. Jacques, Oregon Health \& Science University

(United States)

Ofer Levi, University of Toronto (Canada)

Lev T. Perelman, Harvard University (United States)

Brian W. Pogue, Thayer School of Engineering at Dartmouth (United States)

Bruce J. Tromberg, Beckman Laser Institute and Medical Clinic (United States)

\section{Session Chairs}

1 Dynamic Light Scattering and Speckle I

Ofer Levi, University of Toronto (Canada)

2 Dynamic Light Scattering and Speckle II

Ofer Levi, University of Toronto (Canada)

3 Theory I

Vadim Backman, Northwestern University (United States) 
4 Theory II

Lev T. Perelman, Harvard University (United States)

5 Cells and Tissues I

Adam Wax, Duke University (United States)

6 Cells and Tissues II

Adam Wax, Duke University (United States)

7 Novel Techniques

Dirk J. Faber, Academisch Medisch Centrum (Netherlands)

8 Low Coherence Light Scattering

Dirk J. Faber, Academisch Medisch Centrum (Netherlands) 